10,000 cases of these diseases with this agent, with the happiest results. So uniformly successful has it been that I have in our very extensive practice here, given up the use of quinine and the cinchona alkaloids for the treatment of intermittent fever, and have substituted picrate of ammonia for them. A record was kept of 5000 cases of intermittent fever treated with this agent. Of this number, in nine cases only did it fail to cure, and in these quinine succeeded at once. I usually give it in doses of from one-eighth of a grain to a grain and a half four or five times a day in pill. Half a grain is a fair average dose. Thus given the result is soon visible. In the great majority of the cases treated, half-grain doses in the interval prevented the recurrence of the next attack of the fever, while in about 20 per cent. of the patients two or three attacks followed before the fever ceased. In one case of quartan ague, despite large doses of the salt, the fever recurred for six periods, gradually diminishing in intensity, and then yielded to it. It is equally successful in all the forms of ague, but it is a curious fact that the cases in which it failed to cure were all of the tertian variety. I have also employed this agent in the treatment of twenty-five cases of malarial neuralgia of various nerves, six cases of malarial headache, and one of malarial colic. In all these instances it cured completely and speedily. In remittent fever it does not appear to be of use; six cases of a severe type were treated with it without any effect. Neither is the enlarged spleen of ague benefited by it. I have given it in numbers of such cases in conjunction with ergotine with good results, but such results are secured equally by the use of the ergotine alone.

My experience leads me to the conclusion that in all varieties of intermittent fever, and in malarial neuralgias, picrate of ammonia is a valuable antiperiodic, and it is an efficient and perfect substitute for quinia. It has the following advantages over quinine:- 1 . It is much less expensive. This is an important consideration where, as in Indian practice, hundreds of cases of malarial diseases have to be treated annually. 2. The dose given is very much smaller. 3. It does not produce the unpleasant effects that quinine does-headache, deafness, tinnitus, \&c.; nor does it disorder the digestion or cause nausea, as quinine is apt to do, in the doses in which it has to be given in India.

Amritsar, Punjab, Northern India.

\section{CASE OF TRAUMATIC TETANUS; RECOVERY.}

BY JoHN WeLPTON, L.R.C.P.L., M.R.C.S.

In The LANCET for 1886 two cases of recovery from tetanus (traumatic) are referred to. I had myself a short time ago a successful case.

On Sunday evening, Nov. 7th, I was called to B. B-, a tall powerful man about the age of thirty, and found him suffering from pronounced tetanus, with eyes fixed and staring, hands clasped behind the neck and quite rigid, and opisthotonus so strong that four people could with difficulty keep him down when the spasms were violent, those of the diaphragm being agonising. I placed him under the influence of chloroform, and administered within a short time two drachms of bromide of potassium, together with one drachm of chloral bydrate. I remained with him nearly three hours, when he became quieter and had no more spasms. He was quite well in two or three days. His friends did not know of any wound, but the man explained that in cutting a corn under the right great toe he had cut painfully into the quick three or four days ago. He was a night watchwan at that time and much exposed to the weather.

Ravensthorpe, Yorks

\section{CASE OF MELANOTIC SARCOMA.}

By J. N. BrEDIN, L.K.Q.C.P.I., \&c.

THE patient, a lady, aged fifty-four, first noticed a little spot on the right heel about the last week in October, 1886, thinking it was merely a chilblain or occasioned by a tight boot; it gradually, however, became troublesome, though entirely free from pain, and she then consulted my predecessor Mr. Holt, who advised a consultation. Accordingly, Mr. Rivington was called in, and advised an operation which was performed on Nov. $29 \mathrm{th}$, and seemed effectually to remove the mass. I saw the patient on Dec. 2nd. The growth had none of the characters whatever of melanosis-in fact, up to this time nothing showed itself from October to lead one to be certain. Meanwhile, Mr. Holt and Mr. Rivington suspected melanotic sarcoma. About eight days after the operation several spots of unmistakable melanosis appeared, first on the outside and subsequently on the inside of the thigh, and afterwards on the heel, and was now covering the cicatrix of the wound, which healed without intermission. All these places on the thigh and heel are now becoming confluent and extending and growing rapidly on the skin, without pain. One spot identical in character appeared on the head, and a single one on the back. Neither of these has increased in size, nor have any fresh ones appeared. This is, I presume, a most interesting and remarkable case, and may be seen by any medical man who may appoint an hour with me, as the patient is most willing to be seen by anyone.

Norton Folgate, E.C.

\section{g}

\section{HOSPITAL PRACTICE, BRITISH AND FOREIGN.}

Nulla autem est alia pro certo noscendi via, nisi quamplurimas et morborum et dissectionum historias, tum aliorum tum proprias collectas habere, et inter se comparare.-MoraAGNI De Sed. et Caus. Morb., lib. iv. Procmium.

\section{GUY'S HOSPITAL. \\ SEVEN CONSECUTIVE CASES OF CHARBON TREATED} SUCCESSFULLY BY EXCISION.

(Under the care of Mr. BRYANT.)

WE are able to publish a series of cases of malignant pustule which have occurred in the wards of Guy's Hospital during the course of the last few months, all of them under the care of one surgeon, and successfully treated in a similar manner, by excision, followed in some instances by the application of caustic. This disease is one of which during the last few years several examples have presented themselves in London, chiefly at Guy's and the London Hospitals, and much has been done by the surgeons of these institutions to advance our knowiedge of it. The cases, two of which we give this week, will be read with interest, and the difference in the local and constitutional symptoms carefully noted.

CASE 1.-Charbon of right temporal region, with lymphatic enlargement; excision; skin-grafting; cure. (From notes by Messrs. Du Boulay and F. P. Sarjant.)-Chas. Aaged twenty-nine, a labourer at a lide warehouse, was admitted on Jan. 21st, 1885. The patient's father died of aneurysm of the heart; his mother is living and well. He has been a hard worker, and steady in his habits. Had measles when a baby, and rheumatic fever when he was a boy (this lasted six weeks). About four years ago be was ruptured, and ever since has been wearing a truss. He has of late had some palpitation and nervousness. The patient, who works at a hide factory, was sent to the hospital by the manager (who, he thinks, had the disease himself some years ago). About Christmas last he came as an out-patient with a swelling like a boil on his left cheek. This was opened, and he got well. He was in his usual health up to Monday, the 19th ult., and was at his ordinary occupation, which consisted in handling hides of all kinds, which had come from all parts of the world; they were cow, ox, buffalo hides, and rabbit and opossum skine. While he was at work he felt an itching on his left temple, and putting up his hand felt a sinall pimple about the size of the head of a pin. He felt dull, depressed, and cold that day. On the Tuesday he still felt poorly, the pimple had increased to about the size of a pea, and the surface was black. On the Wednesday it was blacker and larger. During the whole time be had felt cold and unwell, but had kept at work until he was admitted into hospital.

Condition on admission.-The patient is a well-built, healthy-looking young man. When placed in bed he shivered and complained of bad headache. Temperature 